\title{
Arme Vrouwe Justitia
}

Citation for published version (APA):

van Hofstraeten, B. (2019). Arme Vrouwe Justitia: eerst de blinddoek, vervolgens de grijze staar. Maastricht University. https://doi.org/10.26481/spe.20191129bh

Document status and date:

Published: 01/01/2019

DOI:

10.26481/spe.20191129bh

Document Version:

Publisher's PDF, also known as Version of record

\section{Please check the document version of this publication:}

- A submitted manuscript is the version of the article upon submission and before peer-review. There can be important differences between the submitted version and the official published version of record.

People interested in the research are advised to contact the author for the final version of the publication, or visit the DOI to the publisher's website.

- The final author version and the galley proof are versions of the publication after peer review.

- The final published version features the final layout of the paper including the volume, issue and page numbers.

Link to publication

\footnotetext{
General rights rights.

- You may freely distribute the URL identifying the publication in the public portal. please follow below link for the End User Agreement:

www.umlib.nl/taverne-license

Take down policy

If you believe that this document breaches copyright please contact us at:

repository@maastrichtuniversity.nl

providing details and we will investigate your claim.
}

Copyright and moral rights for the publications made accessible in the public portal are retained by the authors and/or other copyright owners and it is a condition of accessing publications that users recognise and abide by the legal requirements associated with these

- Users may download and print one copy of any publication from the public portal for the purpose of private study or research.

- You may not further distribute the material or use it for any profit-making activity or commercial gain

If the publication is distributed under the terms of Article $25 \mathrm{fa}$ of the Dutch Copyright Act, indicated by the "Taverne" license above, 
Prof.dr. Bram Van Hofstraeten Faculteit der Rechtsgeleerdheid

\section{Arme Vrouwe Justitia: eerst de blinddoek, vervolgens de grijze staar}




\section{Arme Vrouwe Justitia: eerst de blinddoek, vervolgens de grijze staar}

Geachte pro-rector, beste Jan,

Geachte collega's,

Beste vrienden, familie, en alle andere toehoorders met een hart voor de Limburgse rechtsgeschiedenis,

Ik sta hier vandaag vooraan om het ambt van bijzonder hoogleraar in de Rechtsgeschiedenis der Limburgse Territoria, ingesteld door het koninklijk Limburgs Geschied- en Oudheidkundig Genootschap, officieel te aanvaarden. Rechtsgeschiedenis der Limburgse Territoria... Een bijzonder rijk, en jawel, een bijzonder levendig vakgebied, met name dankzij mijn illustere voorgangers prof. dr. Ton Gehlen en prof. dr. Louis Berkvens. Toch lokt mijn keuze voor de discipline vaak bezorgde reacties uit. In correct Vlaams: 'Oei Bram, in welk hol van Pluto ga jij je nu ingraven?' Wel, vandaag lijkt mij het uitgelezen moment om iedereen die zich zorgen makt over mijn professioneel en mentaal welzijn gerust te stellen. Limburgse rechtsgeschiedenis is immers, net als elke andere vorm van lokale geschiedschrijving, niet louter een bescheiden niche binnen het ruimere historische bedrijf. Neen, wij handelen dan wel lokaal, maar wij denken minstens continentaal.

\section{Een Legal Revolution en de Great Litigation Decline}

Ik wil jullie dan ook meenemen naar die hete zomer van 1976, toen John A. Dickinson, een Canadese historicus die tijdelijk werkzaam was geweest aan de Franse universiteit van Caen, zijn artikel L'activité judiciaire d'après la procédure civile du baillage de Falaise 1668-1790 eindelijk zag verschijnen in de Revue d'histoire économique et sociale. ${ }^{1}$ Dickinson had vastgesteld dat historici en rechtshistorici tot dan toe met name oog hadden gehad voor de historische ontwikkeling van de criminele rechtspraak tijdens het ancien régime, en veel minder interesse toonden voor de geschiedenis van de civiele of burgerlijke rechtspraak in diezelfde periode. Om invulling te geven aan deze lacune in het rechtshistorische onderzoek besloot Dickinson zich toe te leggen op de gerechtelijke activiteit van de burgerlijke rechtbanken binnen het baljuwschap van Falaise in Noord-West-Frankrijk, en dit voor de periode 1668-1790. Zoals u kan zien op grafiek 1 kwam Dickinson tot een enigszins verrassende vaststelling: een bijzonder sterke afname van de procesvoering gedurende de achttiende eeuw. ${ }^{2}$ Ik zeg verrassend, omdat oudere studies met betrekking tot de criminele rechtspraak een stijging hadden laten zien in de achttiende eeuw.

\footnotetext{
${ }^{1}$ Dickinson 1976.

${ }^{2}$ Grafieken 1, 2, en 3 kwamen tot stand op basis van de beschikbare data in de respectievelijke studies over de Great Litigation Decline. Het moet evenwel benadrukt worden dat deze grafieken slechts vereenvoudigde versies zijn van de trends die door de auteurs geobserveerd werden.
} 


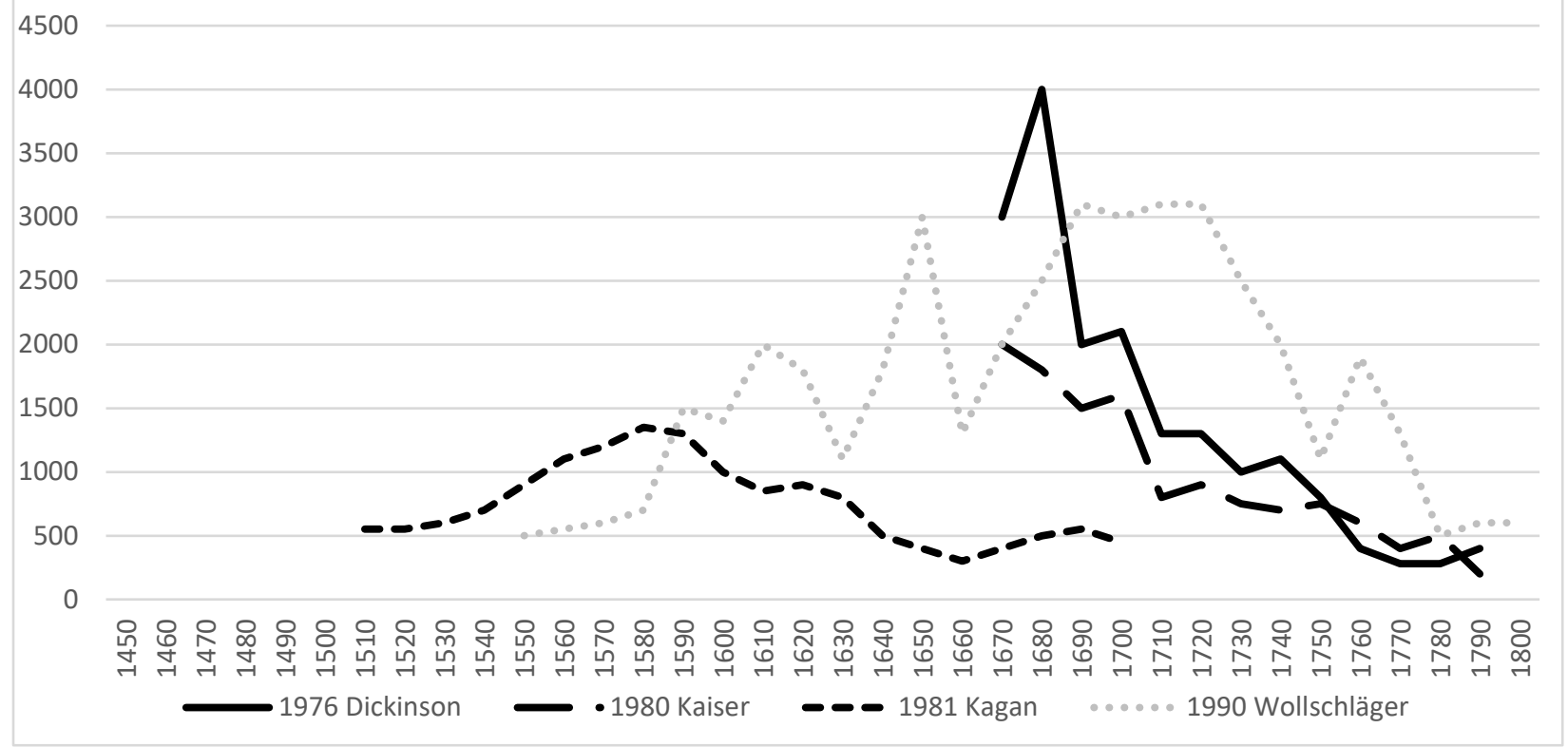

Dickinson kende al snel navolging en stond zo, met zijn onderzoek, aan het begin van een nieuwe productielijn binnen de Europese rechtsgeschiedenis, waarbij de activiteitsgraad en de toegankelijkheid van de civiele rechtspraak centraal staan. Nog geen vier jaar na Dickinson publiceerde Colin Kaiser gelijkaardige resultaten met betrekking tot het Franse Parlement de Paris tijdens de achttiende eeuw: een manifeste afname van het aantal civiele beroepszaken vanaf de tweede helft van de zeventiende eeuw (grafiek 1$){ }^{3}$

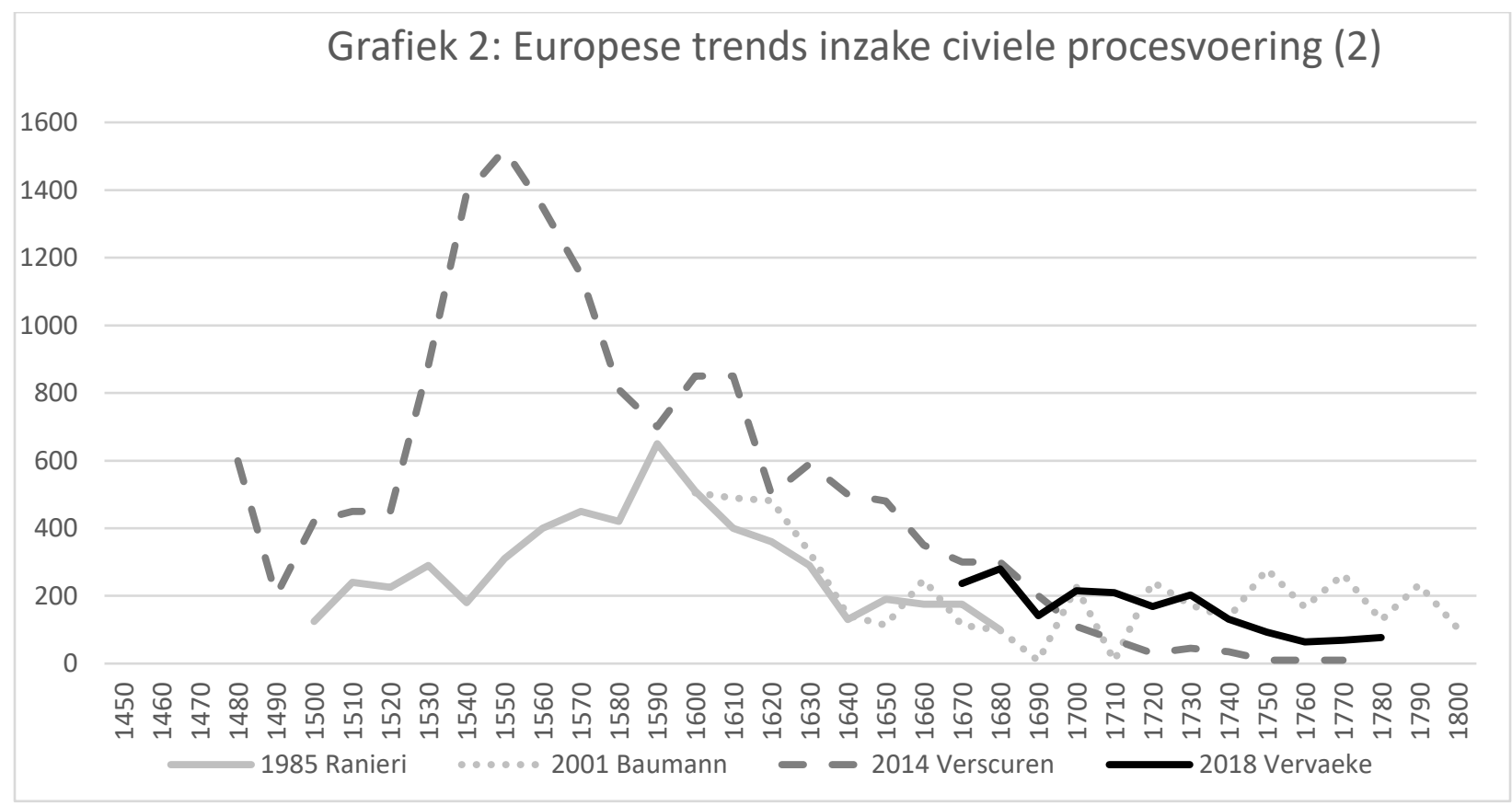

\footnotetext{
${ }^{3}$ Kaiser 1980.
} 
Omwille van de beperkingen van het beschikbare bronnenmateriaal kwam bij Dickinson en Kaiser de nadruk noodgedwongen te liggen op de spectaculaire daling van de civiele procesvoering gedurende de laatste 150 jaar van het ancien régime. Richard L. Kagan, geschiedenisprofessor aan de Johns Hopkins Universiteit van Baltimore, kon een beroep doen op een aanzienlijk uitgebreider bronnenarsenaal. Kagan was overigens geen liefhebber van de wijze waarop toen de rechtsgeschiedenis beoefend werd. Ik citeer: 'Legal history, especially in the hands of lawyers, is best characterized by its overriding concern with institutional developments, self-congratulatory praise of the legal profession, and with the finer points of law. ${ }^{4}$ Einde citaat. Niettegenstaande Kagans misprijzen, ging hij in zijn boek Lawsuits and Litigants in Castile 1500-1700 op zoek naar de procesvoerende aard van de inwoners van het Spaanse Castilië en kwam tot de vaststelling dat de reeds vastgestelde daling aan het einde van het ancien régime voorafgegaan werd door een al even spectaculaire hausse (grafiek 1). Kagan benoemde het fenomeen als een 'legal revolution', m.i. een ietwat ongelukkig gekozen term aangezien een toename van het aantal procesvoerende burgers niet noodzakelijk een juridische of rechtskundige revolutie impliceert. 'Litigeous revolution' lijkt mij een meer passende term. Maar kom, laten we ons niet verliezen in the finer points of terminology.

$\mathrm{Na}$ Kagan volgden nog meer studies waarbij steeds meer Europese territoria aan bod kwamen. Filippo Ranieri en Anette Baumann legden de rechtsprekende activiteit van het Heilig Roomse Rijkskamergerecht onder de loep. Ranieri deed dit tot 1680 en de gelijkenis van de door hem bekomen trend met die van Kagan is treffend (grafiek 2). ${ }^{5}$ Anette Baumann publiceerde aan het begin van de éénentwintigste eeuw een vervolgonderzoek waarbij ook de achttiende eeuw aan bod kwam. ${ }^{6}$ En opnieuw: nihil novi sub sole (grafiek 2). Een ietwat grilliger patroon bekwam Christiaan Wollschläger die de civiele rechtspraak in Bremen kwantificeerde (grafiek 1). ${ }^{7}$

\section{Grafiek 3: Europese trends inzake civiele procesvoering (3)}

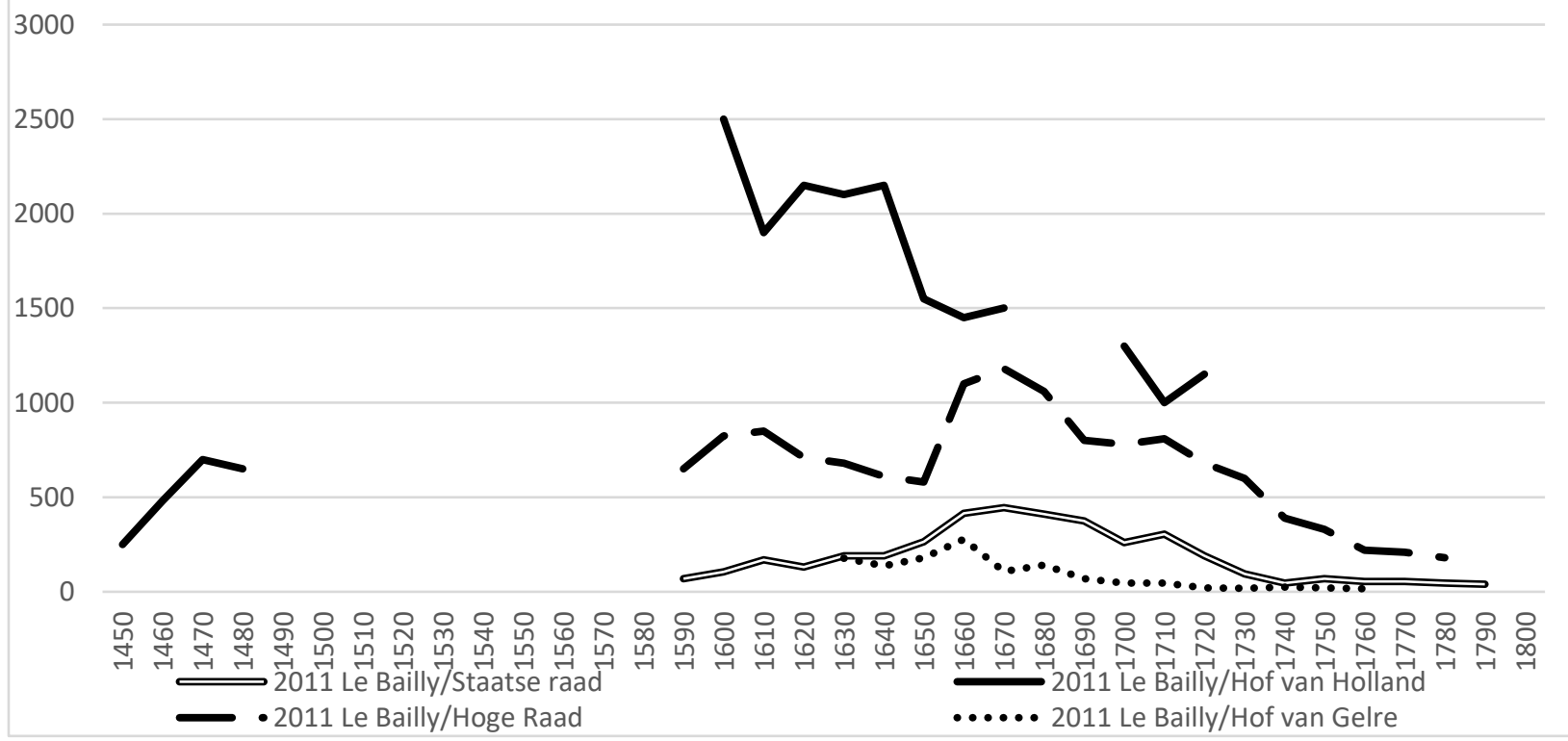

${ }^{4}$ Kagan 1981, xxiii.

${ }^{5}$ Ranieri 1985.

${ }^{6}$ Baumann 2001.

${ }^{7}$ Wollschläger 1990. 
Ook in Engeland was men ondertussen wakker geworden, maar gezien hun bijzondere common law-aard heb ik deze resultaten hier buiten beschouwing gelaten. Ook zij laten overigens gelijkaardige trends zien, met name met betrekking tot de periode $1650-1800 .{ }^{8}$ De term die zij voor het fenomeen lanceerden, namelijk de Great Litigation Decline, is ondertussen gemeengoed geworden, ook onder continentale rechtshistorici.

De afgelopen tien jaar verschenen ook de eerste onderzoeksresultaten betreffende de Great Litigation Decline en de Nederlanden. In het warm aan te bevelen, Nederlands-Belgisch, rechtshistorisch tijdschrift Pro Memorie, liet Marie-Charlotte Le Bailly zien dat de situatie aan de Staatse Raad van Brabant, de Hoge Raad van Holland, Zeeland en West-Friesland, het Hof van Holland en het Hof van Gelre, niet anders was (grafiek 3). ${ }^{9}$ In 2014 bevestigde An Verscuren de dalende trend nog maar eens, dit keer met betrekking tot de Grote Raad van Mechelen (grafiek 2). ${ }^{10}$ Het meest recente onderzoek dateert van 2018 en betrof de lokale rechtbanken van het Brugse Vrije. ${ }^{11}$ Op een ietwat bescheidener schaal, kwam ook Ans Vervaeke tot vergelijkbare resultaten (grafiek 2).

\section{Ontmanteling}

Dames en heren, mijn excuses indien u door de bomen het bos niet meer ziet, maar op basis van bovenstaande grafieken heeft er zich binnen de rechtsgeschiedenis een vrij algemene consensus gevormd omtrent de ontwikkeling van de civiele procesvoering tijdens het ancien régime, waarbij twee pan-Europese fenomenen centraal staan: in de eerste plaats de zogenaamde Great Litigation Decline tijdens de achttiende eeuw en vervolgens Kagans Legal Revolution die zich tijdens de tweede helft van de zestiende eeuw zou hebben voorgedaan. Gezien de geografische reikwijdte en kwantitatieve omvang van beide fenomenen klinkt de roep om verklaringen erg luid. Maar, laten we ons niet laten verleiden door jeugdig enthousiasme, en sta mij toe, tenminste één keer vandaag, de pret te bederven. Voorgaande auteurs hadden steeds tot doel de jurisdictionele of rechtsprekende activiteit van civiele rechtbanken te kwantificeren en daaraan gekoppeld uitspraken te doen over de toegankelijkheid van de rechtspraak voor de rechtzoekenden. Maar hoe meet je dat volume nu exact?

Ranieri en Baumann, met betrekking tot het Rijkskamergerecht, en Le Bailly, met betrekking tot de Staatse Raad van Brabant en het Hof van Gelre, meenden dit te kunnen doen aan de hand van de overgeleverde procesdossiers in de archieven van respectievelijke instellingen. Een dergelijke aanpak levert echter nooit een correcte reflectie van de historische werkelijkheid op. Ten eerste stonden tal van rechtbanken het aan hun rechtzoekenden toe om, na afloop van het proces, het dossier te lichten of mee huiswaarts te nemen. Ten tweede sluit deze methode alle zaken uit die, wegens hun inhoudelijke eenvoud, vrijwel onmiddellijk bij een eerste zitting mondeling werden beslecht. Ik stel dan ook voor niet langer rekening te houden met de resultaten die werden bekomen op basis van deze methode.

Een andere, veel gebruikte methode is gebaseerd op basis van het aantal uitgesproken, of beter geregistreerde, vonnissen. We zien deze methode toegepast bij Dickinson (baljuwschap Falaise), Verscuren (Grote Raad van Mechelen) en opnieuw Le Bailly, maar dan nu met betrekking tot het

\footnotetext{
${ }^{8}$ Brooks 1986; Champion 1997; Horwitz en Polden 1996.

${ }^{9}$ Bailly 2011.

${ }^{10}$ Verscuren 2015.

11 Vervaecke 2018.
} 
Hof van Holland en de Hoge Raad van Holland, Zeeland en West-Friesland. Het grote probleem hier is dat men de toegankelijkheid van de rechtspraak tracht te meten aan de hand van het moment waarop de rechtzoekende de rechtspraak weer verlaat. Men meet de output om de input te kennen. Dit is natuurlijk problematisch, omdat niet elk proces dat werd opgestart ook finaal tot een gerechtelijk vonnis leidde. Partijen konden overlijden tijdens het proces, maar belangrijker nog: partijen konden op elk moment beslissen de rechtsgang, bijvoorbeeld wegens te hoog oplopende kosten, stop te zetten en besluiten buiten de rechtszaal tot een vergelijk te komen.

An Verscuren keek bovendien, net als Kaiser voor het Parlement de Paris, ook naar de zogenaamde distributieregisters, waarin de binnengekomen beroepszaken werden toegewezen aan een magistraat, de zogenaamde rapporteur, die de zaak moest onderzoeken alvorens ze ter beoordeling in camera aan het hof voor te leggen. Ook hier zijn een aantal problemen aan verbonden. In de eerste plaats betreft het hier geen officiële registers. Klerken waren niet verplicht om ze bij te houden. Bovendien hebben we hier te maken met twee instellingen, het Parlement de Paris en de Grote Raad van Mechelen, die hoofdzakelijk als beroepsinstantie fungeerden. Distributieregisters zouden dus een idee kunnen geven van het aantal rechtszaken die het tot het hoogste niveau van de rechtelijke pyramide schopten, maar zeggen bijgevolg niets over de toegankelijkheid van de civiele rechtspraak in het algemeen.

Wat rest ons nu nog? Kagan, Wollschläger en Vervaeke. Wollschläger, die de civiele rechtspraak in Bremen onderzocht, deed dit aan de hand van een bijzonder creatieve, maar zeer betwijfelbare, methodologie, waarbij hij de kwantiteit van de civiele rechtspraak niet meet, maar schat. En ter aanvulling heeft Wollschläger nog een aantal kortere periodes steekproefsgewijs geanalyseerd waarbij hij onder meer de hoeveelheid door de rechtbank gebruikt papier kwantificeerde door de dikte te meten van het bewaarde archiefmateriaal. Wollschläger concludeerde dan ook in alle eerlijkheid: 'As a result, the preindustrial data are subject to error.' ${ }^{12}$ Waarvan akte.

Dames en heren, net als Wollschläger, zijn meerdere van voornoemde auteurs zich wel degelijk bewust van de tekortkomingen van de door hen gehanteerde methodologie en zij weten evenzeer dat ze tot betrouwbaardere resultaten zouden komen indien zij gebruik zouden maken van de, vaak ook beschikbare, rolregisters waarin elke nieuw aangebrachte eis, zij het mondeling of schriftelijk, voor het desbetreffende tribunaal werd geregistreerd. Dit vereist echter monnikenwerk, omdat in de rolregisters ook alle verdere stadia van reeds opgestarte zaken staan vermeld. Alvorens men dus tot kwantificeren over kan gaan, moeten eerst alle afzonderlijke eerste stadia, namelijk het neerleggen van de vordering en het dagen van de beklaagde, uit deze registers gefilterd worden. Deze arbeid is bijzonder tijdrovend of zoals Dickinson het formuleerde: 'Il eût été intéressant d'examiner le nombre de causes, mais ceci impliquerait la confection des listes nominatives des plaideurs et le traitement mécanographique des données. Cela dépasse le cadre de cette etude. ${ }^{13}$ Waarom overstijgt dit de opzet van de studie? Dit ís de opzet van de studie.

Gedegen historisch onderzoek, dames en heren, vraagt tijd, soms heel veel tijd. Richard Kagan en Ans Vervaeke hebben die tijd gelukkig wel genomen, maar bij Kagan blijft het problematisch dat zijn onderzoek zich toespitste op de Cancellaria de Valladolid, het hoogste provinciale hof in de regio Castilië, dat in hoofdzaak als beroepsinstantie fungeerde, waardoor ook zijn gegevens ons

${ }^{12}$ Wollschläger 1990, 264.

${ }^{13}$ Dickinson 1976, 152, n.22. 
weinig vertellen over de daadwerkelijke toegankelijkheid van de civiele rechtspraak in eerste instantie. Rest ons enkel nog het werk van Ans Vervaeke dat de kwaliteitstest lijkt te doorstaan. Zij heeft wel, op basis van de rolboeken, elke individuele eis op het laagste rechtsprekende niveau van het Brugse Vrije weten te identificeren, kwantificeren en analyseren, waardoor we eindelijk wetenschappelijk onderbouwde uitspraken kunnen doen over de activiteit en de toegankelijkheid van de civiele rechtspraak gedurende het ancien régime. En inderdaad, er lijkt zich een afname voor te doen tijdens de achttiende eeuw (grafiek 2). Maar, dames en heren, ik ga een tweede keer de pret moeten bederven, want bij de laatste horde ging het toch mis. Stel dat de 280 eisen, die Vervaeke voor het jaar 1680 identificeerde, slechts door 60 verschillende eisers/rechtzoekenden werden neergelegd, terwijl de 131 eisen in 1740 door 120 verschillende eisers werden neergelegd, dan nam de toegankelijkheid van de rechtspraak toe in tegenstelling tot wat men op basis van de activiteit of het aantal neergelegde eisen zou vermoeden. Door uitsluitend de activiteit te meten kan men niets betrouwbaars zeggen over de toegankelijkheid. Uitspraken over de toegankelijkheid van de rechtspraak voor de justitiabele vragen daarentegen om een onderzoek naar de groep rechtzoekenden in plaats van vonnissen, procesdossiers, distributieboeken, neergelegde eisen, enzovoort.

Wat weten we nu met zekerheid? Niets. De Great Litigation Decline is, net als de Legal Revolution, niet meer dan een hypothese, een veronderstelling, een mogelijkheid, maar geen feit en al zeker geen zekerheid. Het blijft natuurlijk wel kriebelen. Wat gebeurde er dan echt met de toegankelijkheid van de civiele rechtbanken tijdens het ancien régime? Ik heb mij dan ook tot doel gesteld, in het kader van deze bijzondere leerstoel, de toegankelijkheid van de Maastrichtse rechtspraak tijdens het ancien régime te onderzoeken om op die manier meer gefundeerde uitspraken te kunnen doen met betrekking tot de zojuist beschreven en zogezegde pan-Europese fenomenen.

\section{Maastricht: bestuur en rechtspraak}

De stad Maastricht kende gedurende het ancien régime een bijzondere bestuursvorm, de zogenaamde tweeherigheid of condominium. De term verwijst naar een bestuursvorm waarbij het opperste gezag over de stad en zijn inwoners gedeeld werd door twee heren, in dit geval de Prinsbisschop van Luik enerzijds en de Hertog van Brabant, later de Staten-Generaal van de Noordelijke Nederlanden, anderzijds. Vandaar het stedelijk credo: Eén heer, geen heer; twee heren, één heer. Tijdens de middeleeuwen heeft dit gedeeld gezag van de twee heren een bestuurlijke en juridische organisatie tot stand gebracht waarbij steeds rekening gehouden werd met het tweeledig karakter van de Maasstad.

Een cruciaal moment in de bestuurlijke ontwikkeling van de stad is het jaar 1413, wanneer de stedelijke raad, die instond voor het bestuur van de stad, ook een aantal lagere rechtsprekende bevoegdheden kreeg toebedeeld. Tegelijkertijd werden de Brabantse en Luikse schepenbanken gepromoveerd tot zogenaamde 'hooggerechten', exclusief belast met de hoge jurisdictie. Als dusdanig bleef de rechtspraak, met betrekking tot de hoge jurisdictie, gescheiden tussen een Luiks en een Brabants Hooggerecht. Ten aanzien van de lagere jurisdictie vond er een samensmelting plaats in het zogenaamde 'Indivies Laaggerecht'. In wezen vormde dit Laaggerecht een segment of afdeling van de stedelijke, indivieze raad. Een aantal leden van deze stedelijke raad kwamen op dinsdag samen om kleinere, hoofdzakelijk civielrechtelijke, geschillen te beslechten, en vormden in die hoedanigheid het Indivies Laaggerecht. 
In de zestiende eeuw werden vier commissarissen-deciseurs aangesteld, twee uit Luik en twee uit Brabant, om onder meer rechtszaken in beroep te behandelen, maar nog belangrijker was hun taak om toezicht te houden op het naar behoren functioneren van de stedelijke instellingen. Om bij te kunnen sturen waar nodig, werd hen het recht verleend om plaatselijke bestuursverordeningen uit te vaardigen, de zogenaamde 'recessen'.

\section{Civiele procesvoering in Maastricht: de Giant Litigation Decline}

Het is aan de hand van de procesvoering voor het Indivies Laaggerecht dat ik de toegankelijkheid van de Maastrichtse, civiele rechtspraak tijdens het ancien régime zal onderzoeken. Laten we onszelf dus naar de Grote Staat, huisnummers 9 en 11, begeven alwaar, alvorens de V\&D zich hier art deco-gewijs vestigde in de jaren dertig van de twintigste eeuw, twee huizen stonden genaamd De Lanscroon en De Liebaert. Het was in deze panden dat het Indivies Laaggerecht zitting hield, althans tot de tweede helft van de zeventiende eeuw wanneer er naar het nieuwe stadhuis verhuisd werd. Iedere dinsdagochtend om 9 uur hielden de twee burgemeesters en acht gezworen raden samen zitting in De Lanscroon. De Luikse en Brabantse secretarissen registreerden er, steeds in het Middel-Nederlands overigens, de nieuw aangebrachte eisen, alsook de voortgang van reeds lopende zaken, in de zogenaamde rolregisters.

Na twee jaar turven heb ik voor 33 steekproefjaren uit de periode 1430-1800 alle nieuw opgestarte procedures geïdentificeerd en opgelijst, inclusief de namen van de partijen en de juridische aard van het geschil. ${ }^{14}$ In totaal gaat het om 13.175 rechtszaken, opgestart door 10.978 verschillende eisende partijen. Uitgezet op een tijdlijn levert dit grafiek 4 op. Een drietal redenen maken deze grafiek bijzonder. Ten eerste blijkt de Great Litigation Decline niet langer een fenomeen te zijn dat hoofdzakelijk met de achttiende eeuw geassocieerd moet worden, maar in werkelijkheid een neerwaartse trend of Giant Litigation Decline omvat die zich al vanaf 1485 manifesteerde. Sommigen onder u zullen mij willen attenderen op de heropleving van de rechtsprekende activiteit tijdens de periode 1650-1720, maar dit is slechts een laatste stuiptrekking van Vrouwe Justitia. Ik kom daar later nog op terug. Ten tweede blijkt de zogenaamde Legal Revolution zich niet in de tweede helft van de zestiende eeuw af te spelen, maar veel vroeger, namelijk in de tweede helft van de vijftiende eeuw, althans wat de stad Maastricht betreft.

\footnotetext{
${ }^{14}$ De onderzochte rolregisters en hun archivalische vindplaatsen worden opgelijst in bijlage.
} 


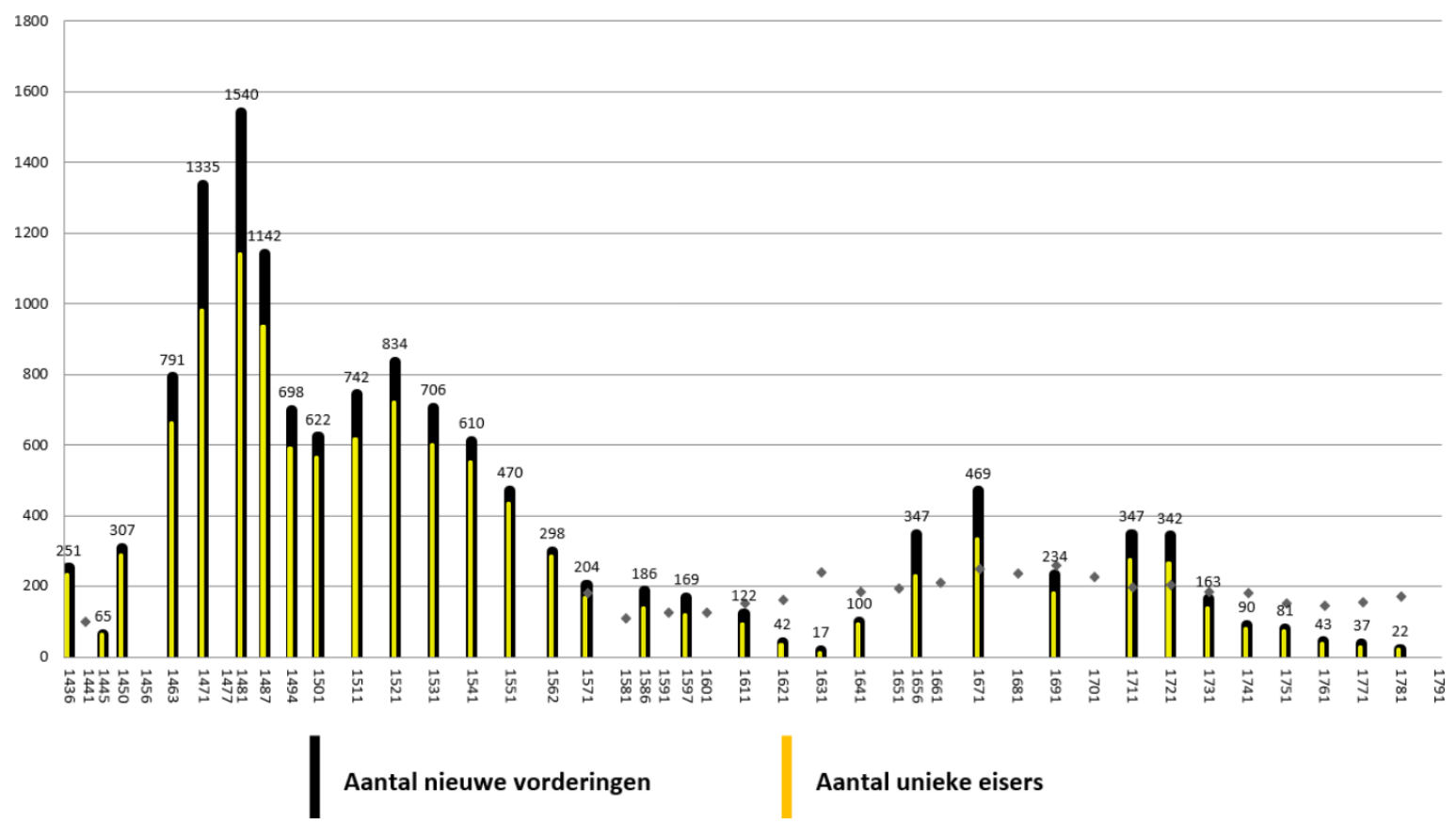

Een derde tot de verbeelding sprekende vaststelling is het absolute dieptepunt tijdens het jaar 1641. Waar in het jaar 1481 nog 1540 klachten werden neergelegd bij het Indivies Laaggerecht door 1140 verschillende eisers, maakten voor het ganse jaar 1641 slechts vier verschillende eisende partijen de wandeling naar De Lanscroon. Het lijkt erop dat het Indivies Laaggerecht totaal niet meer functioneerde. Het dieptepunt is immers niet te wijten aan gebreken of lacunes in de rolregisters. Als het Indivies Laaggerecht inderdaad niet langer naar behoren functioneerde, dan kan mogelijk een verklaring gevonden worden in de resolutie- of recesboeken van de zogenaamde commissarissen-deciseurs. En inderdaad, een reces van 1627 blijkt verhelderend: 'gemerckt alle saeken meest worden bedinght extraordinarie soe wel int hooghe als leeghe gerichte tot grooten last ende verdriet vande arme ende schaemele partijen, die daerdoere met dobbele rechten van secretarissen ende procureurs worden oeverlast' ${ }^{15}$ Naast de gewone of ordinarisse rolprocedure blijkt er dus een tweede, extra-ordinarisse of buitengewone, rolprocedure te bestaan. Deze staat evenwel niet in het Receuil der Recessen van 1665 beschreven en moet nog nader onderzocht moet worden. Mogelijk was zij op dat moment reeds afgeschaft. Er zijn immers geen extra-ordinarisse rolregisters bewaard die dateren van na 1650 en uit het reces van 1627 blijkt dat deze procedure bovendien zeer nadelig was voor het minderbedeelde deel van de bevolking. De commissarissen-deciseurs ordonneerden dan ook dat vorderingen niet langer mochten gepresenteerd of aangezet worden op het extra-ordinarisse rolregister zonder een mondelinge toestemming van de rechter. ${ }^{16}$ De rolregisters van de buitengewone procedure zijn enkel bewaard gebleven voor de periode 1600-1650, net wanneer de gewone procedure in diep verval was geraakt. Vermoedelijk heeft zij dan ook enkel gedurende deze vijf decennia bestaan. Met betrekking tot onze steekproef is enkel het jaar 1641 ter inzage beschikbaar. De overige registers blijken in een te precaire staat te verkeren, maar op basis van de

\footnotetext{
${ }^{15}$ Maastricht, RHCL, Commissarissen-deciseurs van beide Heren (bestuurlijk), inv.nr. 20.002, nr. 6, Recesboeken 1580-1758, Reces van 1627, f.193r.

${ }^{16}$ Ibidem.
} 
gegevens in de buitengewone rolregisters van 1641, kan men besluiten dat het ogenschijnlijke dieptepunt tijdens de eerste helft van de zeventiende eeuw in werkelijkheid minder dramatisch was. Activiteit en toegankelijkheid van het Indivies Laaggerecht bleven - met 96 nieuwe unieke eisers in de extra-ordinarisse rolregisters van het jaar 1641- op een niveau dat minder uitzonderlijk is dan slechts vier nieuwe unieke eisers per jaar.

Dames en heren, wie weet waarom de ganzen blootsvoets gaan? Het formuleren van een verklaring voor de vastgestelde trends wordt echter bemoeilijkt omdat we hier te maken hebben met een fenomeen dat bijna 350 jaar nodig had om tot voltooiing te komen. Bijgevolg kunnen evenementiële gebeurtenissen, zoals hongersnoden, pestepidemieën of periodes van oorlog, uitgesloten worden als mogelijke verklaringsgrond. Zij zouden slechts kortstondige wijzigingen in het Maastrichtse procespatroon kunnen verklaren. Grafiek 4 laat echter zien dat noch de belegeringen van Maastricht in 1579 en 1632, noch de Franse bezettingen van de stad gedurende de periodes 1673-1678 en 1748-1749 een verstorend effect hebben gehad op de procesvoering in de stad. Ook economische crises of bloeiperiodes blijken om dezelfde reden ontoereikend om de langdurige neerwaartse trend te verklaren, net als éénmalige bestuurlijke ingrepen waarbij bijvoorbeeld de competenties van het Indivies Laaggerecht worden ingeperkt - wat zich overigens niet heeft voorgedaan. De demografie daarentegen zou wel een geloofwaardige factor kunnen zijn. Het onderzoek van Kemp naar de bevolkingscurve van Maastricht tijdens het ancien régime laat echter zien dat er - althans wat Maastricht betreft - geen correlatie bestond tussen demografie en procesvoering. ${ }^{17}$ Soms nam het aantal processen inderdaad toe als het bevolkingscijfer steeg; maar soms nam het aantal processen af als de bevolking aangroeide.

Een interessante denkpiste heb ik kunnen terugvinden in de bestaande literatuur aangaande procespatronen tijdens de negentiende en twintigste eeuw. ${ }^{18}$ Hierin wordt gesteld dat procesvoering, vanuit sociaal perspectief, curvi-lineair is. Dit houdt in dat zeer ingrijpende sociale veranderingen, zoals bijvoorbeeld ten gevolge van de industriële revolutie in de negentiende eeuw of de transitie van traditionele gemeenschappen naar moderne samenlevingen in koloniaal Afrika tijdens de twintigste eeuw, steeds leiden tot een sterke toename van de procesvoering, gevolgd door een afname - van zodra nieuwe oplossingen werden gevonden voor de nieuwe problemen - om uiteindelijk te stabiliseren op een bepaald niveau. Opvallend is dat grafiek 4 haast een perfect voorbeeld is van een curvi-lineaire ontwikkeling: eerst een curve, dan quasi-lineair. Zou het dan mogelijk zijn dat Maastricht tijdens de tweede helft van de vijftiende eeuw, op sociaal vlak, een dusdanige transitie heeft doorgemaakt die verantwoordelijk kan zijn voor de vastgestelde hausse in procesvoering? Gezien het aanhoudend stedelijk karakter van de stad Maastricht, betwijfel ik dit ten zeerste. Desalniettemin houd ik de optie open.

Lange tijd ben ik er van overtuigd geweest dat de hoofdoorzaak voor de afname gezocht moet worden binnen de rechtspraak zelf, en met name hoe deze functioneerde. In de Nederlanden kende de zogenaamde romano-canonieke procedure immers haar doorbraak tijdens de zestiende eeuw waarna zij vervolgens algemeen verspreid geraakte. Deze nieuwe procedure kwam ter vervanging van de middeleeuwse mondelinge procedure waarbij de eiser en de gedaagde voor het Indivies Laaggerecht verschenen, de eiser zijn klacht formuleerde, de gedaagde reageerde en de zaak vervolgens, meestal met een gedingbeslissende eed, werd beslecht. Ondanks het vaak irrationele karakter van de bewijsvoering blonk deze middeleeuwse procedure uit in efficiëntie en

${ }^{17}$ Kemp 1962.

${ }^{18}$ Abel 2009; Van Loon en Langerwerf 1990. 
een hoge mate van toegankelijkheid: ze was kort en goedkoop, en door haar eenvoud was juridische bijstand door een advocaat, en de hieraan verbonden kosten, overbodig. De schriftelijke romano-canonieke procedure daarentegen was veel complexer, schriftelijk, langduriger, en bijgevolg ook duurder. Nadat de eiser zijn eis of aanspraak had neergelegd en de gedaagde was komen opdagen, moest deze zijn antwoord op de aanspraak schriftelijk aanbieden. Zoals onderstaande afbeelding laat zien kon, bij een dergelijke procedure, het proces tot wel tien en zelfs meer stappen doorlopen, terwijl bij elke nieuwe stap gerechtskosten aangerekend werden. Bovendien werd, gezien de complexiteit van de procedure, bijstand door een advocaat of procureur onontbeerlijk, wat procederen nog duurder maakte. En toch blijkt uit onze data dat de invoering van de romano-canonieke procedure bij het Indivies Laaggerecht in de jaren 1570 nauwelijks invloed heeft uitgeoefend op de mate van procesvoering in Maastricht. De sterkste afname van de procesvoering in Maastricht vond immers plaats vóór het moment waarop de romano-canonieke procedure werd geïntroduceerd.

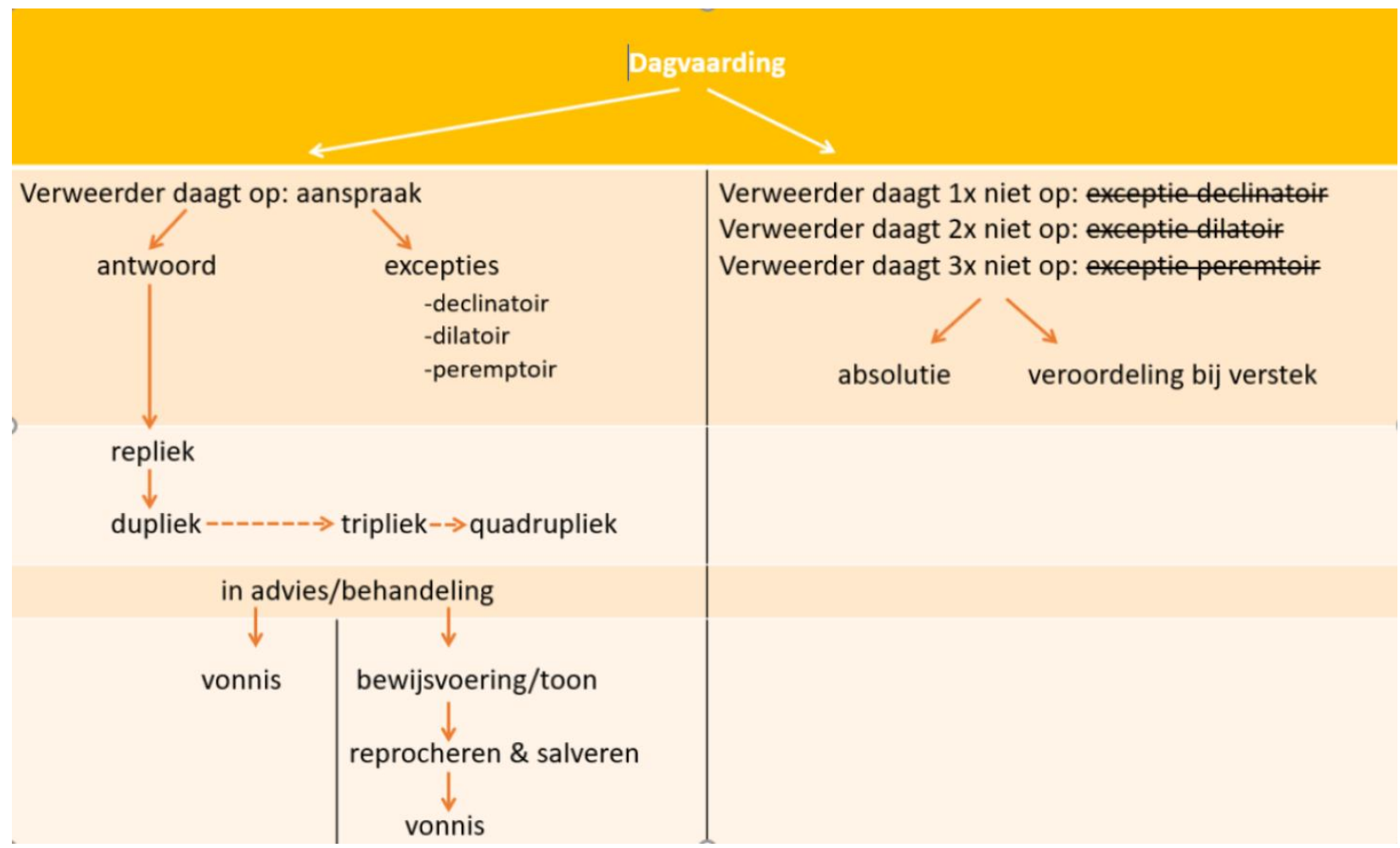

Is de sterke afname dan misschien gelieerd aan een afgenomen vertrouwen in de rechters, een wantrouwen dat op zijn beurt het gevolg is van een te hoge mate van rechtsonzekerheid? Van zodra partijen hun rechten kennen en weten op basis van welk recht de burgemeesters en gezworen raden van het Indivies Laaggerecht zullen oordelen, dan zullen zij sneller geneigd zijn om juridische stappen te ondernemen, dan wanneer hier onduidelijkheid over bestaat. In Maastricht werd de mate van rechtszekerheid aanzienlijk versterkt in 1665 door het te boek stellen van het lokale gewoonterecht in het zogenaamde Recueil der Recessen, wat dus kan worden aangeduid als een mogelijke oorzaak voor de korte heropleving van de procesvoering in Maastricht tijdens de tweede helft van de zeventiende eeuw. De daling hieraan voorafgaand zou dan in verband gebracht kunnen worden met een toenemend wantrouwen ten aanzien van het Indivies Laaggerecht, bijvoorbeeld omdat zij zich steeds vaker gaan beroepen op het voor de modale burger vaak onbekende Romeinse recht. Of deze aanname plausibel is, vraagt om een 
onderzoek naar de eventuele academische vorming van de burgemeesters en gezworen raden van Maastricht. M.i. lijkt deze veronderstelling weinig aannemelijk, aangezien de commissarissendeciseurs in 1599 nog opdragen aan alle leden van zowel het Laag- als beide Hooggerechten om zich bij belangrijke processen te laten adviseren door zogenaamde meesters in de rechten. ${ }^{19}$ De maatregel doet vermoeden dat de Maastrichtse rechters zelf, aan de vooravond van de zeventiende eeuw, nog steeds geen universitaire (lees: juridische) vorming hadden genoten.

Tot dusver heb ik één constante uit het ancien régime nog niet behandeld, namelijk het feit dat de advocatuur gedurende 300 jaar kop van jut was. Maar heeft ze ook daadwerkelijk boter op haar hoofd? De Brugse rechtsgeleerde, Joost De Damhouder, meende van wel. In 1567 publiceerde hij een oratie getiteld Van de inslockinge der processen. ${ }^{20}$ Hierin ging hij fel tekeer tegen de advocaten als verantwoordelijken voor de overdaad aan processen waarmee de rechtbanken te kampen kregen aan het begin van de zestiende eeuw. Het zijn zij - 'O schandelijcke advocaten ende hongerige procureurs' - die, voor eigen gewin en niet uit liefde voor de waarheid, zowel arm als rijk aanmoedigen om te procederen van zodra zich daar enige gelegenheid toe lijkt aan te dienen. Zo doen zij, aldus De Damhouder, tal van mensen in de poel der armoede belanden en zaaien ze tweedracht in de samenleving. Enkel de overheid kon z.i. een einde stellen aan dergelijke onbehoorlijke processen en de te lichtveerdelijck procederenden. Verwijzend naar Justinianus en het Romeinse recht, pleitte De Damhouder voor bestraffing van deze praktijken met een geldboete, en zelfs lijfstraffen als men de boete niet kon betalen, want: 'die het niet heeft in't gelleken, moet de straf lijden in zijn velleken'. ${ }^{21}$ De Damhouders oratie biedt mogelijk aanknopingspunten voor de hausse van de procesvoering die ook in Maastricht aan het einde van de vijftiende eeuw vastgesteld kan worden.

Naast toenames in de procesvoering, kan de advocatuur echter ook voor afnames verantwoordelijk geacht worden. Zo werd in 1618, door de commissarissen-deciseurs, voor het eerst melding gemaakt van de achterstand bij justitie vanwege het 'consenteren somwijlen van ses oft meer termijnen tot groote beswaernisse vande partyen ende postpositie vande iusticie'. ${ }^{22}$ Verwijzend naar een eerder reces van 1600 mocht vervolgens alleen nog maar geprocedeerd worden met een aanspraak, antwoord, repliek en dupliek. ${ }^{23}$ Triplieken, quadruplieken, enzovoort waren vanaf nu uit den boze, tenzij er in de dupliek cruciale nieuwigheden vastgesteld konden worden. De advocatuur werd niet expliciet vermeld, maar het is duidelijk dat zij delen in de verantwoordelijkheid ten aanzien van de eindeloze procedures. Dit blijkt ook uit latere recessen. In 1648 en 1654 werden de advocaten wel nadrukkelijk geviseerd: hun geschriften bleken veel te uitvoerig, met name door onnodige herhalingen en drogredenen, wat de procedures deed vertragen en de procespartijen op onnodige kosten joeg 'tot affscrick van partijen' ${ }^{24} \mathrm{U}$ moet immers weten dat advocaten per bladzijde werden betaald. De rechters werden vanaf nu opgedragen dat ze bij het taxeren van de gerechtskosten niet langer naar de lengte van de geschriften moeten kijken, maar wel naar de inhoud van de zaak. Bovendien werd geordonneerd dat vanaf nu alle kleinere zaken, die niet boven de 100 gulden gingen, mondeling moesten

\footnotetext{
${ }^{19}$ RHCL, 20.002, nr. 6, Reces van 1599, f.116v.

${ }^{20}$ De oratie werd als inleiding op zijn Practycke in civile saecken gepubliceerd. (De Damhouder 1626, Oratie des autheurs.)

${ }^{21}$ Ibidem.

${ }^{22}$ RHCL, 20.002, nr. 6, Reces van 1618, f. 169v.

${ }^{23}$ Ibidem, f. 170r.

${ }^{24}$ RHCL, 20.002, nr. 6, Recessen van 1648 en 1654, f. 226v-227r en f. 245r.
} 
worden bepleit en de plano worden afgedaan, zonder enige vorm van schriftelijke procedure. ${ }^{25}$ De kritiek op de langdradigheid en breedsprakigheid van de advocaten werd nog meermaals herhaald in 1680, 1688 en $1738 .{ }^{26}$ Het bleek een hardnekkig probleem.

Overigens, advocaten lagen ook om andere redenen onder vuur. Zo werd in 1742 een resolutie overeengekomen tegen advocaten en procureurs die vergaderden in 'bier-, caffee-, wijn-, ende brandewynshuysen' en de kostprijs van wat zij hier verteerden doorrekenden aan hun cliënten. ${ }^{27}$ Eerder, in 1692, werd reeds besloten om een reglement op te stellen inzake het salaris van advocaten, procureurs, notarissen, chirurgijns en apothekers 'tot voorcominghe van groote abuysen'. ${ }^{28}$ In 1722 kwam er een nieuw reglement dat betrekking had op het salaris van de advocaten in het bijzonder. ${ }^{29}$ Elke handeling werd minutieus getaxeerd. Elke consultatie met een cliënt kostte twee gulden. Een verplaatsing naar het Indivies Laaggerecht om het verschijnen van de gedaagde vast te stellen werd getaxeerd op drie gulden. Duurde de verplaatsing langer dan een uur, dan mocht een surplus van twee gulden aangerekend worden. Indien een zaak zwaarwichtiger bleek en wanneer ze in de fase van de bewijsvoering of toon kwam, dan kostte elke bijkomende bijeenkomst drie gulden. Moest de advocaat voor de zaak buiten de stad reizen, dan kreeg hij acht gulden per dag bovenop de transportkosten. Maaltijden mocht hij niet aanrekenen, maar voor elke brief die hij aan zijn cliënt moest schrijven, kreeg hij één gulden. Enzovoort. Enzovoort.

Uit de kritiek blijkt dat de wanpraktijken van de advocaten met name voor vertraging zorgden, maar de justitiabelen ook op onnodig hoge kosten joegen. Wat de kostprijs van procederen als mogelijke oorzaak voor de Great Litigation Decline betreft, hink ik nog op twee gedachten. Enerzijds blijkt uit de recessen van de commissarissen-deciseurs en de maatregelen die zij nemen (onder meer gericht tegen de advocatuur) een duidelijke bezorgdheid over de minderbedeelde en schamele leden van de samenleving en hun toegang tot de rechtspraak. ${ }^{30}$ Maar bij een rechtsgeleerde als De Damhouder staat dan weer te lezen dat de 'hittigen brand tot lichtveerdig procederen' niet alleen te wijten is aan de rijken, maar ook aan vele armen die niet aflaten van deze pleitlust: 'Iae selfs sodanighen die naulicx ghenoech en hebben waer mede haren hongerigen maech te versadigen'. ${ }^{31}$ En De Damhouder gaat nog een stap verder: armen vrezen niets en zullen sneller procederen dan rijken, want wie niets heeft, kan - mede dankzij de bijstand van een pro deo-advocaat - niets verliezen en alleen maar winnen. Rijke burgers, daarentegen, twijfelen sneller om te procederen vanwege het risico om in hun eigen vermogen beschadigd te worden. Hoe dan ook, procederen bleef het risico inhouden dat men - als verliezende partij - tot het betalen van de gerechtskosten veroordeeld kon worden. In Maastricht werden anno 1652 de gerechtskosten voor zowel het Indivies Laaggerecht als beide Hooggerechten vastgelegd in een officiële prijslijst, een prijslijst die overigens onveranderd is gebleven voor de resterende duur van het ancien régime. ${ }^{32}$ Wat er ook van zij: het probleem blijft dat de daling zich inzette in de zestiende eeuw, een periode dat de kostprijs van procederen nog uiterst laag moet zijn geweest door de gangbare, snelle, mondelinge procedure waar (nog) geen advocaten aan te pas kwamen.

\footnotetext{
${ }^{25}$ Ibidem, f. 227r-v.

${ }^{26}$ RHCL, 20.002, nr.6, Recessen van 1680, 1688 en 1738, f. 297v, f. 328v-329v en f. 520v-521v.

${ }^{27}$ RHCL, 20.002, nr.6, Reces van 1742, f. 533r-534v.

${ }^{28}$ RHCL, 20.002, nr.6, Reces van 1692, f. 340v.

${ }^{29}$ RHCL, 20.002, nr.6, Reces van 1722, f. 435v-437r.

${ }^{30}$ Zie boven, maar ook: RHCL, 20.002, nr.6, Recessen van 1627 en 1648, f. 193r en f. 226v.

${ }^{31}$ De Damhouder, 1626, Oratie des autheurs.

${ }^{32}$ RHCL, 20.002, nr.6, Reces van 1652, f. 239v-241r.
} 
Het ziet er dus naar uit dat de drietand 'complexe procedure' en 'wanpraktijken binnen de advocatuur', en de hieruit voortvloeiende 'hoge kostprijs van procederen', een fundamentele rol hebben gespeeld in de immer afnemende toegankelijkheid van de rechtspraak tijdens het ancien régime, tenminste wat betreft de zeventiende en achttiende eeuw. De korte heropleving tijdens de periode 1650-1720 laat zien dat het ingrijpen van de overheid zijn vruchten afwerpt: een toegenomen rechtszekerheid met de publicatie van het Recueil der Recessen, maatregelen tegen de breedsprakigheid van de advocatuur, een verbod op de extra-ordinarisse procedure, het opstellen van een officiële prijslijst van de gerechtskosten, enzovoort.

De grote uitdaging blijft het formuleren van een verklaring voor de immense toename van procesvoering tijdens de tweede helft van de vijftiende eeuw en de hierop volgende decimering van het aantal gevoerde processen voor het Indivies Laaggerecht. Hopelijk brengt de toekomst, en de inhoudelijke analyse van de gevoerde processen en procespartijen in het bijzonder, uitsluitsel.

Vast staat dat de toegang tot de rechtspraak in Maastricht nooit zo laagdrempelig is geweest als aan het einde van de vijftiende eeuw. Het toeval wil dat in dezelfde periode Vrouwe Justitia voor het eerst met een blinddoek werd afgebeeld. Ze werd opzettelijk verblind, maar in positieve zin, om te kunnen oordelen zonder aanschijn des persoons. Vandaag heb ik proberen aanschouwelijk te maken dat vanaf datzelfde moment Vrouwe Justitia ook in negatieve zin werd verblind. Vanaf 1485 werden de eerste symptomen van de grijze staar of cataracta zichtbaar, een oogaandoening waarbij de ooglens vertroebelt en het zicht geleidelijk aan vermindert. Over een periode van 300 jaar bleek Vrouwe Justitia steeds minder in staat zich te kwijten van haar quintessentiële taak, namelijk de plicht tot justitia omnibus oftewel gerechtigheid garanderen voor iedereen. En dit is bijzonder problematisch. Want van zodra een overheid niet langer kan voorzien in deze behoefte, dan ondermijnt ze haar eigen bestaansreden. Dankzij de rechtsantropologie weten we immers dat een objectieve rechtsbedeling één van de hoofdredenen moet geweest zijn waarom de mens zijn recht tot eigenrichting heeft opgegeven en zich is gaan organiseren in en onderwerpen aan statelijke instellingen. Dit is een cruciaal gegeven dat ook moderne overheden vandaag de dag steeds in het achterhoofd moeten houden wanneer zij menen te moeten besparen op de rechtspraak of de druk op de rechtbanken menen te moeten verlagen door steeds meer rechtszoekenden in de richting van alternatieve vormen van geschillenbeslechting te sturen. De Maastrichtse commissarissen-deciseurs waren zich hier nog steeds goed van bewust toen ze in 1651 de 'goede ende wettige rechtspleginge' omschreven als 'de ziele van een politique lichaem' en benadrukten dat geen stad of gemeenschap kan bestaan zonder. ${ }^{33}$

${ }^{33}$ RHCL, 20.002, nr.6, Reces van 1651, f. 234v. 


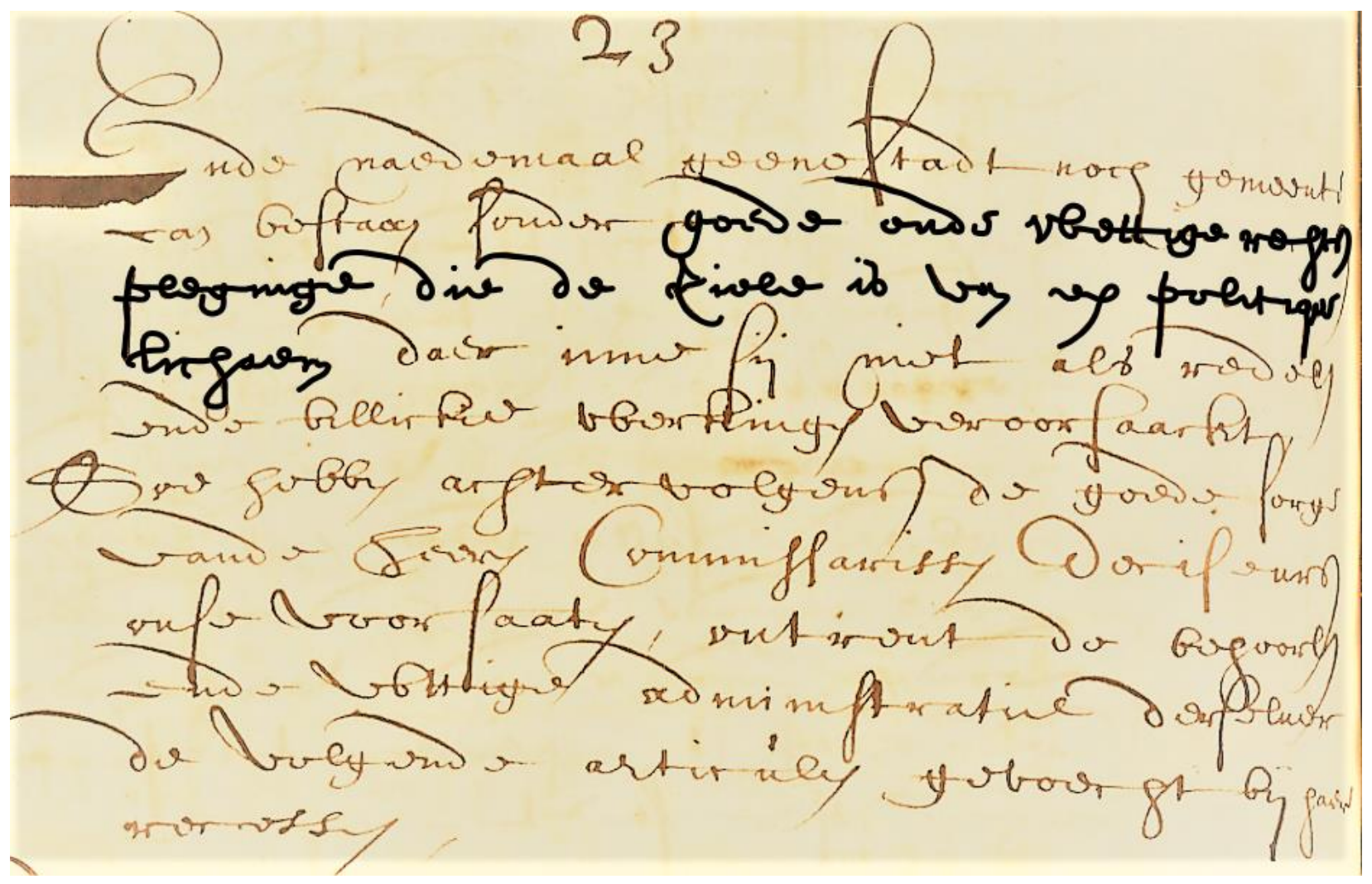

\section{Dankwoord}

Het is evenzeer bekend dat een oratie niet kan bestaan zonder dankwoord. Uiteraard is het onmogelijk om hier iedereen te vermelden die op één of andere manier, groot of klein, aan mijn ontwikkeling als mens en rechtshistoricus een bijdrage heeft geleverd. Voor een aantal mensen zou ik toch graag een uitzondering willen maken.

In de eerste plaats wil ik het hoofdbestuur van het koninklijk Limburgs Geschied- en Oudheidkundig Genootschap, de leden van het curatorium van mijn leerstoel, het College van Bestuur van de Universiteit Maastricht, en de decaan van onze Faculteit der Rechtsgeleerdheid bedanken voor het in mij gestelde vertrouwen. Het stemt mij bovendien uiterst tevreden dat zowel het koninklijk LGOG als het faculteitsbestuur elkaar, na dertig jaar, nog steeds weten te vinden in de overtuiging dat mijn leerstoel een verrijking is voor beide partijen. Moge het steeds groeiend aantal studenten dat kiest voor het keuzeblok Comparative Legal History of the MeuseRhine EURegion hiervan het bewijs zijn.

Dat ik hier nu kan staan, heb ik uiteraard ook aan mijn voorgangers te danken, prof. Ton Gehlen en prof. Louis Berkvens. Beste Louis, nu sta ik waar jij ooit stond. Jij bent uiteraard mijn doktorvater, maar ik heb steeds meer het gevoel dat ik vooral in de jaren volgend op mijn promotie het meest van jou heb geleerd. Hoewel je nu officieel met emeritaat bent gegaan, hoop ik toch dit in de toekomst te kunnen blijven doen. 
Vervolgens zou ik mijn ouders willen bedanken. Hier in Maastricht hoor ik vaak studenten die worstelen met leenstelsels, beurzen en bijbaantjes. Dankzij mijn ouders, heb ik zelf nooit ook maar één euro aan mijn eigen studie moeten besteden, zelfs niet na het maken van verkeerde keuzes. En dit kiezen geschiedde overigens allemaal in absolute vrijheid, geen quid pro quo: nooit heb ik ook maar enige druk moeten ervaren bij het maken van keuzes die mijn toekomst betroffen. Dikke merci!

Hildegard en René, sommige academici zullen hun promotie of oratie bestempelen als de belangrijkste dag uit hun professionele loopbaan. Maar als ik zelf terugkijk op de afgelopen zestien jaar, dan is misschien wel die ene Paasmaandag in 2016 bij jullie thuis de meest cruciale dag geweest in mijn carrière tot dusver. Feestdag of niet, jullie deur stond open om in allerijl nog te sleutelen aan mijn presentatie voor het nakende VIDI-interview. We weten ondertussen hoe dat is afgelopen. Mijn oprechte dank daarvoor.

Mariolina Eliantonio, weet je nog dat ik vergeten was je in het dankwoord van mij proefschrift expliciet te vermelden. Ik ga dat bij deze goedmaken. Jij bent immers degene die mij, aan het begin van ons promotieonderzoek hier in Maastricht, uit mijn hol van Pluto heeft getrokken, en letterlijk de faculteit heeft ingetrokken. Zonder jou zat ik mogelijk nog steeds als een kluizenaar verscholen in een of andere studio in Veldwezelt. Dankjewel!

Mieke Olaerts, in theorie ben je uitsluitend voor onze promovendi de officiële vertrouwenspersoon. Ik ben al even geen promovendus meer, maar voor mij maak je al meer dan elf jaar een uitzondering. En ondanks momenten van éénrichtingsverkeer ben je steeds blijven klaarstaan om, van zodra daar nood aan was, de bij wijlen ondraaglijke echtheid van het bestaan te relativeren. Ik ben je daar heel veel dank voor verschuldigd. En als het om het onderhoud van je achtertuin gaat, beloof ik bij deze plechtig daar nooit nog beloftes over te doen.

Mariolina en Mieke zijn naast collega's ook vrienden, maar ik heb ook vrienden die - gelukkig maar - geen collega's zijn: Dieter Vandenbroucke, Gert Gielis en Joris Smeets, allemaal voortreffelijke historici, maar nog voortreffelijker praatpalen, reisgezellen, tooghangers en concertgangers. Ook zij hebben doorheen de jaren hun plaats hier dubbel en dik verdiend.

En tenslotte is er Koen Vissers. Weet je nog die dag in Zuid-Frankrijk in de auto toen je vrouw Maj ons vroeg aan te geven wie onze beste vriend was? Het werd toen even heel stil, ja zelf wat ongemakkelijk, in die auto, nietwaar. Wij zijn immers mannen van de Kempen en weinig woorden, en we gaan ons dat dan ook geen tweede keer aandoen.

Ik heb gezegd. 


\section{Literatuur}

Abel 2009: R.L. Abel, 'Forecasting civil litigation', in: DePaul Law Review 58/2 (2009) 425-450.

Bailly 2011: M.C. Le Bailly, 'Langetermijntrends in de rechtspraak bij de gewestelijke hoven van justitie in de Noordelijke Nederlanden van ca. 1450 tot ca. 1800', in: Pro Memorie: bijdragen tot de rechtsgeschiedenis der Nederlanden 13/1 (2011) 30-67.

Baumann 2001: A. Baumann, Die Gesellschaft der Frühen Neuzeit im Spiegel der Reichskammergerichtsprozesse. Eine sozialgeschichtliche Untersuchung zum 17. und 18. Jahrhundert. Quellen und Forschungen zur Höchsten Gerichtsbarkeit im Alten Reich 36 (Keulen, Weimar en Wenen 2001).

Brooks 1986: C.W. Brooks, Pettyfoggers and Vipers of the Commonwealth. The 'Lower Branch' of the Legal Profession in Early Modern England. Cambridge Studies in English Legal History (Cambridge 1986).

Champion 1997: W.A. Champion, 'Recourse to the law and the meaning of the great litigation decline 1650-1750', in: C.W. Brooks en M. Lobban eds., Communities and courts in Britain 1150-1900 (Londen 1997) 179-98.

De Damhouder 1626: Damhouder, J. De, Practycke in civile saecken: seer nut, profijtelijck ende nodigh allen schouten, borghemeesteren, magistraten ende andere rechteren, Den Haag 1626.

Dickinson 1976: J.A. Dickinson, 'L'activité judiciaire d'après la procédure civile. Le bailliage de Falaise, 1668-1790', in: Revue d'histoire économique et sociale 54 (1976) 145-168.

Horwitz en Polden 1996: H. Horwitz en P. Polden, 'Continuity or change in the Court of Chancery in the seventeenth and eighteenth centuries?', in: Journal of British Studies 35/1 (1996) 24-57.

Kagan 1981: R.L. Kagan, Lawsuits and litigants in Castile 1500-1700, Chapel Hill 1981.

Kaiser 1980: C. Kaiser, 'The Deflation in the Volume of Litigation at Paris in the Eighteenth Century and the Waning of the Old Judicial Order', in: European Studies Review 10 (1980) 309-336.

Kemp 1962: A.G.H. Kemp, 'Het verloop van de bevolkingscurve van Maastricht tot 1830', in: Werken uitgegeven door Limburgs Geschied- en Oudheidkundig Genootschap 4 (1962) 339-362.

Ranieri 1985: F. Ranieri, Recht und Gesellschaft im Zeitalter der Rezeption. Eine rechts- und sozialgeschichtliche Analyse der Tätigkeit des Reichskammergerichts im 16. Jahrhundert, Keulen en Wenen 1985.

Van Loon en Langerwerf 1990: Loon, F. Van en Langerwerf, E., 'Socioeconomic development and the evolution of litigation rates of civil courts in Belgium, 1835-1980', in: Law and Society Review 24/2 (1990) 283-298.

Verscuren 2015: A. Verscuren, The Great Council of Malines in the 18th century. An Aging Court in a Changing World? Studies in the History of Law and Justice 3 (Heidelberg, New York, Dordrecht en Londen 2015).

Vervaecke 2018: A. Vervaecke, Met recht en rede(n). Toegang en gebruik van burgerlijke rechtbanken in het Brugse Vrije (1670-1795), Brussel 2018. 
Wollschläger 1990: C. Wollschläger, 'Civil litigation and modernization: the work of the municipal courts of Bremen, Germany, in five centuries, 1549-1984', in: Law and Society Review (1990) 261-282. 


\section{Bijlage: Onderzochte rolregisters van de Luikse en Brabantse secretarissen.}

20.085A: Indivies Laaggerecht Maastricht: archief (geïnventariseerd)

Rolregisters van de Luikse en Brabantse secretarissen

$\mathrm{N}^{\circ} 4484$ (1436 en 1445), $\mathrm{N}^{\circ} 4485$ (1450), $\mathrm{N}^{\circ} 4486$ (1463), $\mathrm{N}^{\circ} 4487$ (1471), $\mathrm{N}^{\circ} 4490$ (1481), $\mathrm{N}^{\circ} 4489$ (1487), $\mathrm{N}^{\circ} 4491$ (1494), $\mathrm{N}^{\circ} 4492$ (1501), $\mathrm{N}^{\circ} 4494$ (1511), $\mathrm{N}^{\circ} 4496$ (1521), $\mathrm{N}^{\circ} 4500$ (1531), $\mathrm{N}^{\circ} 4504-4505$ (1541), $\mathrm{N}^{\circ} 4509$ (1551), $\mathrm{N}^{\circ} 4512-4513$ (1562), $\mathrm{N}^{\circ} 4515$ (1571).

Rolregisters van de Luikse secretarissen

$\mathrm{N}^{\circ} 4520$ (1586), $\mathrm{N}^{\circ} 4525$ (1597), $\mathrm{N}^{\circ} 4528$ (1611), $\mathrm{N}^{\circ} 4531$ (1621), $\mathrm{N}^{\circ} 4532$ (1631 en 1641), $\mathrm{N}^{\circ} 4535-4536$ (1656), $\mathrm{N}^{\circ} 4551-4552$ (1671), $\mathrm{N}^{\circ} 4567$ (1691), $\mathrm{N}^{\circ} 4576-4577$ (1711), $\mathrm{N}^{\circ} 4583$ (1721), $\mathrm{N}^{\circ} 4588$ (1731), $\mathrm{N}^{\circ} 4591$ (1741), $\mathrm{N}^{\circ} 4592$ (1751), $\mathrm{N}^{\circ} 4594$ (1761), $\mathrm{N}^{\circ} 4596$ (1771), $\mathrm{N}^{\circ} 4597$ (1781).

Rolregisters van de Brabantse secretarissen

$\mathrm{N}^{\circ} 4620$ (1586), $\mathrm{N}^{\circ} 4622$ (1597), $\mathrm{N}^{\circ} 4681$ (1611), $\mathrm{N}^{\circ} 4686$ (1621 en 1631), $\mathrm{N}^{\circ} 4687$ (1641), $\mathrm{N}^{\circ} 4692$ (1656), $\mathrm{N}^{\circ} 4708-4709$ (1671), $\mathrm{N}^{\circ} 4726$ (1691), $\mathrm{N}^{\circ} 4738-4739$ (1711), $\mathrm{N}^{\circ} 4746$ (1721), $\mathrm{N}^{\circ} 4751-4752$ (1731), $\mathrm{N}^{\circ} 4754$ (1741), $\mathrm{N}^{\circ} 4755-4756$ (1751), $\mathrm{N}^{\circ} 4758$ (1761), $\mathrm{N}^{\circ} 4759$ (1771), $\mathrm{N}^{\circ} 4761$ (1781). 